\title{
Trans-operative reattachment of crown-root fragment: fundamentals of the technique and a case report
}

\author{
Colagem trans-cirúrgica de fragmento corono-radicular: fundamentos da técnica e relato de caso clínico
}

José Carlos Viana RIBEIRO'

Marília Mota SILVA'

Carlos Augusto de Oliveira FERNANDES'

\begin{abstract}
The functional and aesthetic restoration of crown-root fractured anterior teeth with biological width involvement represents a challenge to the clinician, because it requires a multidisciplinary approach. The trans-operative fragment reattachment technique is a feasible and advantageous alternative since it makes it possible to reestablish the original aesthetics and function of the fractured tooth in a single appointment. This work presents the fundamentals of this technique, highlighting its advantages, indications and limitations. The applications of the surgical and restorative procedures are demonstrated by way of a case report.
\end{abstract}

Indexing terms: Dental bonding. Periodontium. Tooth fractures.

\section{RESUMO}

As fraturas dentais representam as lesões de maior incidência nos traumatismos bucais e causam um impacto negativo sobre a mastigação, fonação e estética. A restauração estético-funcional de dentes anteriores com este tipo de fratura associada a um envolvimento do espaço biológico representa um desafio ao clínico, pois exige uma abordagem multidisciplinar. Nestes casos é necessário realizar um diagnóstico cuidadoso e devem ser observados os diversos aspectos que podem direcionar a seleção da técnica restauradora mais adequada. A técnica de colagem trans-cirúrgica do fragmento dental constitui, atualmente, uma alternativa viável e bastante vantajosa, pois representa um tratamento mais conservador, seguro, rápido e, acima de tudo, eficiente em devolver a forma, o contorno, a translucidez, a textura superficial, o perfil de emergência natural do dente e a harmonia do sorriso em uma única sessão clínica. O presente trabalho se propõe a apresentar, através de um relato de caso clínico, os fundamentos da técnica de colagem de fragmento corono-radicular simultânea ao procedimento de cirurgia periodontal, destacando suas indicações, vantagens e limitações.

Termos de indexação: Colagem dentária. Periodonto. Fraturas dos dentes.

\section{INTRODUCTION}

The restoration of the tooth structure, which combines the preservation of healthy tissue, aesthetics, function and longevity, represents the main objective of restorative dentistry. Ideally, a dental restoration should be as strong as natural teeth and have an appearance that renders it imperceptible, even for the most aesthetically demanding patients. Therefore, in many clinical situations, the reattachment of dental fragments represents the best option for restoring fractured anterior teeth, as it is a simple, efficient way of restoring the original color, shape, contour, surface texture, natural occlusal alignment ${ }^{1}$, iridescence and fluorescence of the fractured tooth ${ }^{2}$. According to Conceição et al. $^{3}$, the reattachment of fragments offers the following advantages: a positive psychological effect on the patient, who will keep his/her own natural tooth; an extremely conservative treatment which preserves the tooth structure; the possibility of obtaining excellent aesthetics due to the characteristics of translucence and surface texture of the dental enamel; maintaining the occlusal function in enamel, which results in the maintenance of the mechanical properties of resistance to the abrasion of the fractured tooth and the antagonist; simplicity, safety and low cost of the technique. Other authors, such as Farik et al. ${ }^{4}$, Segun et al. ${ }^{5}$ and Canoglu et al. ${ }^{6}$ have confirmed

\footnotetext{
${ }^{1}$ Universidade Federal do Ceará, Faculdade de Farmácia, Odontologia e Enfermagem, Departamento de Dentística Restauradora. Rua Monsenhor Furtado, s/n., Rodolfo Teófilo, 60430-350, Fortaleza, CE, Brasil. Correspondência para / Correspondence to: JCV RIBEIRO. Email: <jcarlosvr@gmail.com>
} 
these beneficial aspects of the technique of reattaching fragments.

Dental fractures make up the vast majority of lesions resulting from dental trauma. According to Oliveira et al. ${ }^{7}$, between $30 \%$ and $50 \%$ of injuries affecting the hard tissue of the tooth are crown-root fractures. In the literature, there are several classifications of dental fracture. The most common of these is based on the WHO International Classification of Diseases to Dentistry and Stomatology (1995), which classifies fractures according to magnitude:

a) crown fractures: enamel; enamel and dentin without pulp involvement; enamel and dentin with pulp involvement;

b) crown-root fractures: with or without pulp involvement; with or without involvement of the biological width.

Crown-root fractures with periodontal involvement are challenging for the clinical dentist as access to the area of the fracture is more complicated and the frequent need to restore the biological width involved requires multidisciplinary involvement. According to Olsburgh et al. ${ }^{8}$, when there is, effectively, invasion of the biological width, there exists a number of treatment options:

a) removal of the fragment without any surgical procedure: the restoration is performed using composite resin at the level of the gingival or slightly subgingival margin, leaving a strip of exposed dentin. The prognosis is questionable;

b) gingivectomy with or without osteotomy: this permits the reattachment of the fragment in just one clinical appointment, as it enables exposure of the fracture's cervical margin and the proper isolation of the operative field. When the reattachment option is decided upon, an osteotomy may, if required, be carried out just to keep the cementation line $1 \mathrm{~mm}$ inside the bone crest in order to allow fresh conjunctive attachment and the attachment of the clamp for absolute isolation. The epithelial junction will be inserted on the surface of the fragment (enamel/cement). This will only be possible if there is good adaptation of the fragment to the remnant since, in this way, the composite margin on the fracture line will be kept to a minimum. In cases where there is imperfect adaptation at the cervical margin, or where it is decided to perform a resin restoration (in the absence of fragments), the restoration of biological width should be complete, providing space for the conjunctive attachment, epithelial junction and gingival sulcus. Periodontal surgery is not the best treatment option in regions where there are significant aesthetical demands, such as the buccal surface of the upper incisors;

c) orthodontic extrusion: recommended for areas where the aesthetic is paramount. Here, the disadvantage is the recovery time (between 90 and 120 days) and the frequent need for aesthetic periodontal correction for the recontouring of the bone margin;

d) immediate surgical extrusion: a more traumatic procedure, which always results in the need for endodontic treatment. The reattachment may only be performed after a period of retainer usage. The risk of external resorption cannot be ruled out.

The resolution of crown-root fractures requires the professional to perform a precise diagnosis as the very signals of the fracture orient the treatment. The most important aspects to be analyzed are the adaptation of the fragment to the tooth remnant, fragment size and hydration, the location and extent of the fracture and periodontal involvement, pulp condition, occlusion and the patient's functional aesthetic expectations ${ }^{3-9}$.

As can be seen, there are different types of treatment for the various types of crown-root fracture. The present study intends to show, by way of the reporting of a clinical case, the technique of reattaching crownroot fragments at the same time as the periodontal surgical procedure, demonstrating that correct diagnosis can determine the indication of the most appropriate treatment.

\section{CASE REPORT}

A 19-year-old male, patient sought the assistance of the Dental Clinic at the Federal University of Ceará (UFC), presenting with a fracture in tooth 11 resulting from a bicycle accident some 45 days previously, according to the report provided by the patient himself. During this period of time, the patient reported that the tooth was submitted to endodontic treatment, as he was in acute pain. The fragments were brought in a water-filled container. In the clinical examination with a periodontal probe and periapical $x$-ray, an oblique crown-root fracture was confirmed, with a mesiodistal and buccal-palatal inclination, with invasion of the biological width on the palatal surface (figure 1). The two fragments fitted well to the remaining tooth, although there was a mesial portion on the buccal surface with loss of tooth structure (figure 2). They were cleaned with $2 \%$ chlorhexidine solution 
and packed in saline solution, stored under refrigerated conditions. Based on the fragment characteristics, the size and surface area being favorable to adhesion and a good fit to the remnant, particularly in the cervical area, the recommended treatment for the resolution of the case was the reattachment of the fragments, with a restoration in composite resin of the areas with loss of tooth structure.

The area of involvement of the biological width was restricted to the palatal surface, reaching as far as the cervical third of the root. Accordingly, the proposed plan was to undertake exploratory periodontal surgery to be able to view the cervical margin of the fracture and to restore the biological width, simultaneously with the reattachment of the fragments. Gingivectomy, either with or without an osteotomy, would be limited to the palatal portion to avoid aesthetic damage to the buccal region. At the time of the initial appointment, in addition to a clinical and radiographic examination, instruction on oral hygiene, prophylaxis and the topical application of fluoride were also provided.

At the second appointment, after infiltration anesthesia, the palatal gingivectomy was performed with an intra-sulcular incision from tooth 12 to 21 and a full mucoperiosteal flap with an internal bevel around $2 \mathrm{~mm}$ from the gingival margin. The flap was retracted and the area was scraped with a curette in order to expose the bone tissue in the region of tooth 11. It was found that the cervical limit of the fracture was at the same level as the bone crest. The osteotomy was carried out using a chisel, removing a $1 \mathrm{~mm}$ strip of bone crest, just enough to enable absolute isolation and the subsequent conjunctive reattachment (figure 3). After absolute isolation, the tooth remnant was cleaned with a solution of $2 \%$ chlorhexidine and the fragments were positioned to check the cervical adaptation. The pulp chamber and cervical third of the root canal were cleared of any obstruction in order to increase the area of adhesion. Both the tooth remnant and the fragments were etched with $37 \%$ phosphoric acid for 15 seconds in enamel and dentin, copiously rinsed with an air/ water spray, once again for 15 seconds, and then dried with gentle jets of air and absorbent paper, so as not to dehydrate the dentin. Two layers of Adper Single Bond ${ }^{\circledR}$ (3M Espe) adhesive were then applied to the tooth remnant and the fragments (figure 4), as per manufacturer's recommendations, and were then photopolymerized for 40 seconds on each surface. The fragments were then glued to the remnant using a flow applied composite resin in color A3 (Natural Flow ${ }^{\circledR}$, DFL) and the pulp chamber was filled with micro-hybrid composite resin (figure 4). The central portion of the buccal surface, whose fragment was not recovered, was restored with micro-hybrid A3-dentin composite resin (Point- $4{ }^{\circledR}$, Kerr), A3-enamel (Esthet- $X^{\circledR}$, Dentsply) and translucent resin (Charisma ${ }^{\circledR}$, Kulzer) (figure 5). The periodontal surgical procedure was concluded following the removal of the absolute isolation, with copious irrigation of the flap using saline solution and suturing of the gingival papillae. The occlusion was evaluated in the centric position and protrusive excursion so as to eliminate any premature contact or occlusal interference with tooth 11. A periapical $x$-ray was performed to evaluate the fragment fit. The patient was assessed after 7 days, and then again at 15 and 30 days, to monitor the healing process and he reported being completely satisfied with the aesthetic outcome. The clinical and radiographic evaluation after 1 year showed a satisfactory recovery of the periodontium, absence of periodontal pockets or bleeding on probing and quite a favorable aesthetic outcome, with re-established contour, natural texture and emergence profile of the fractured tooth (figure 6).

The present study is in compliance with the Helsinki Declaration (2000), since all the procedures performed are based on generally accepted scientific principles founded on the applicable scientific literature. The patient volunteered to take part in the study and was informed in advance of all the procedures to be carried out, authorizing the use of the images by way of a consent form.
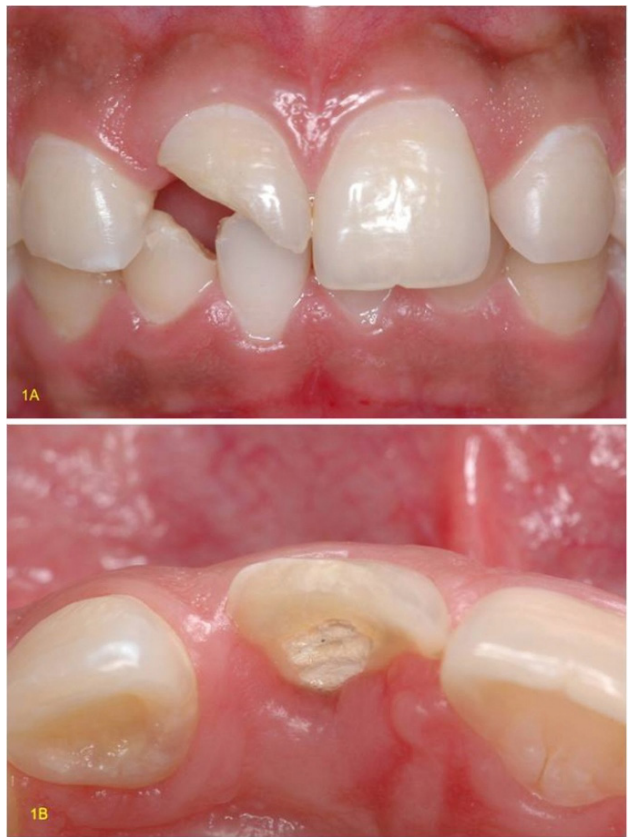

Figure 1. Initial patient condition. A) Oblique fracture of tooth 11, in the mesiodistal direction; B) Palatal view showing inflammation of the gingival margin due to invasion of the biological width. 

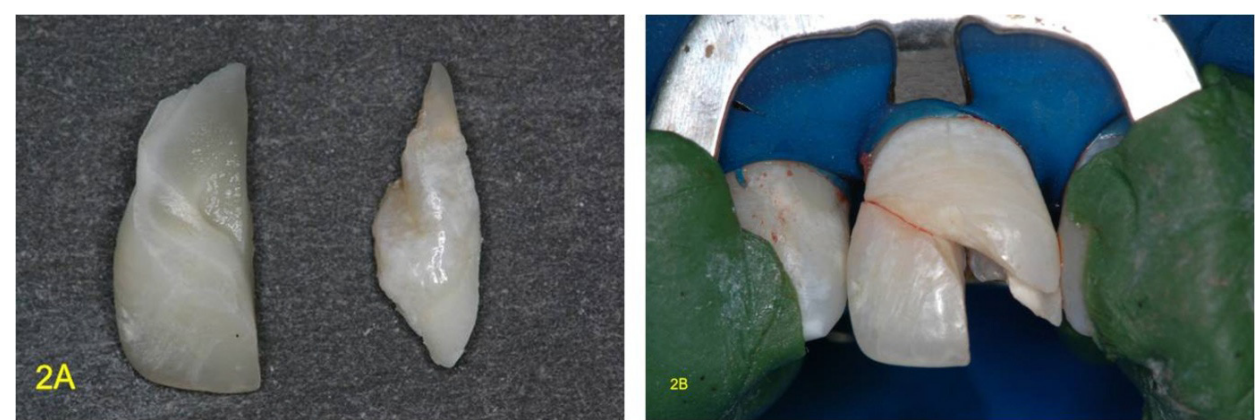

Figure 2. A) Crown-root fragments. Fragment size favors adhesive procedures. B) Adaptation of the fragments to the tooth remnant with loss of structure in the mesiobuccal portion and along the bond line.
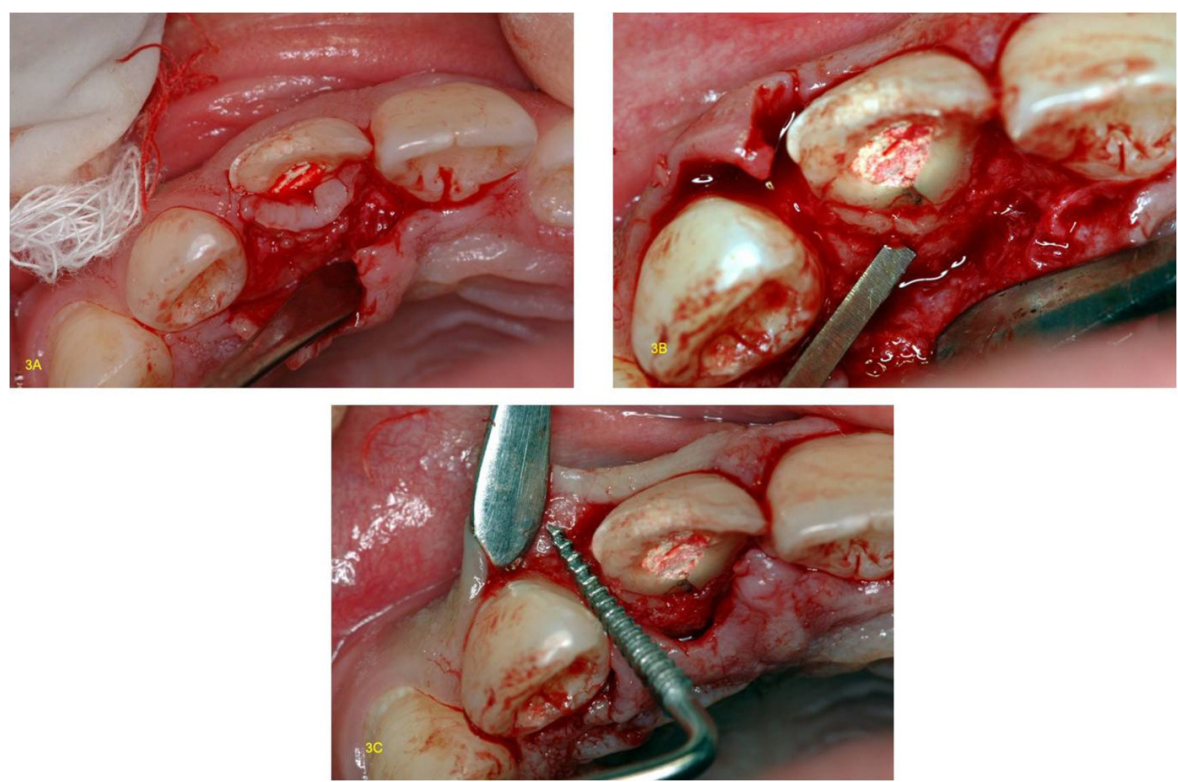

Figure 3. A) Incision and retraction of the flap; B) Palatal osteotomy with chisel, removing $1 \mathrm{~mm}$ of bone crest; C) Smoothing of the bone crest using a file.
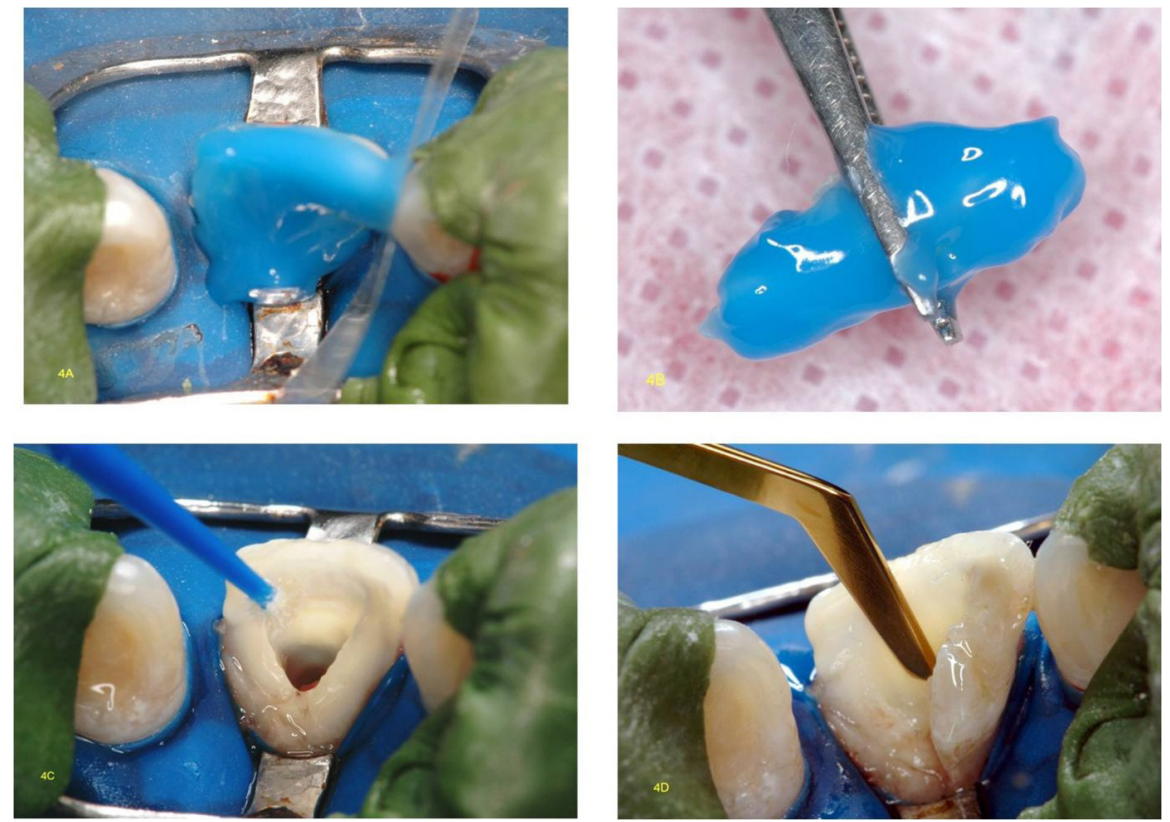

Figure 4. A-B) Total acid etching of the tooth remnant and fragments under absolute isolation; C) Application of adhesive to enamel and dentin; note pulp chamber being cleared of any obstruction; D) Reattachment of the first fragment and filling of the pulp chamber. 

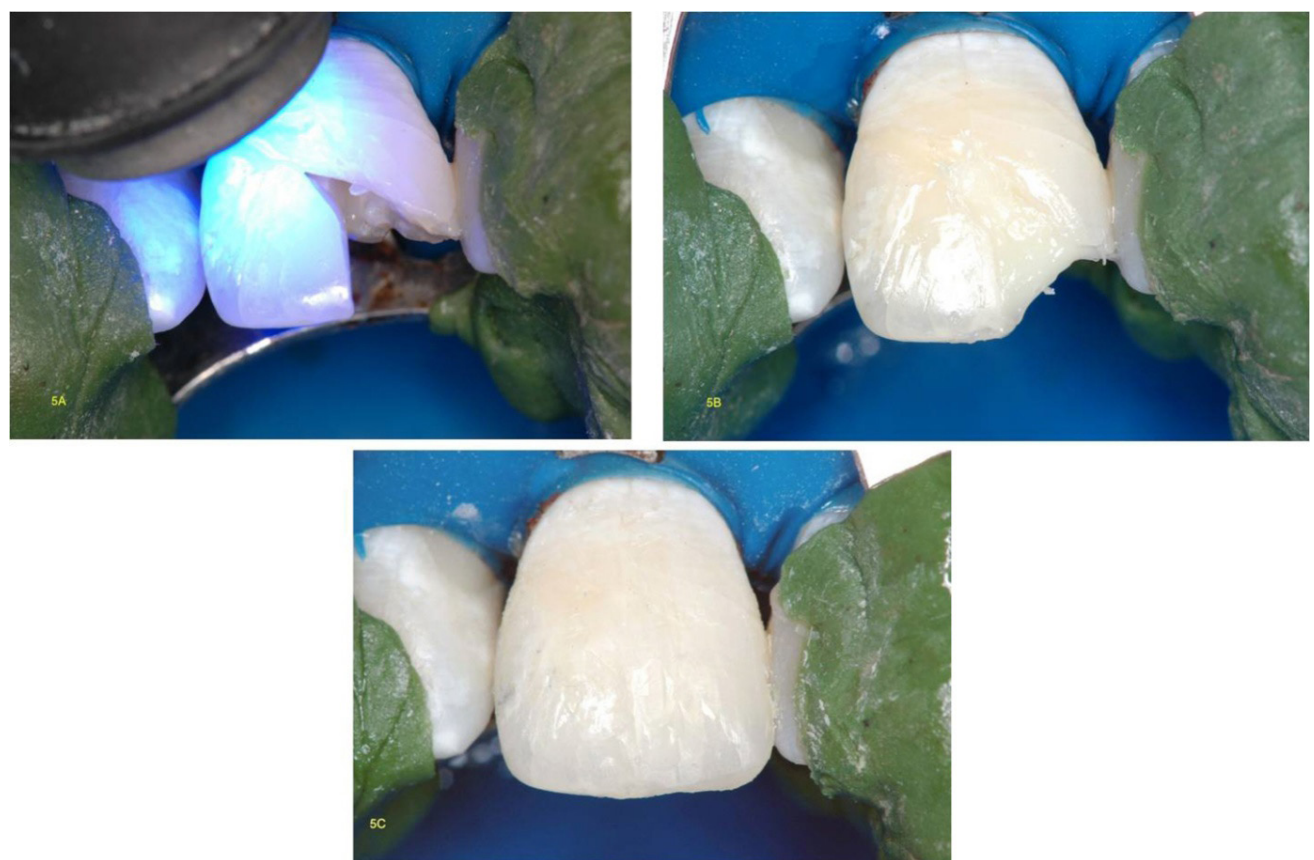

Figure 5. A) Reattachment and photopolymerization of the second fragment; B-D) Restoration of lost tooth structure with micro-hybrid dentin-resin, enamel and translucent resin. (buccal and palatal view).
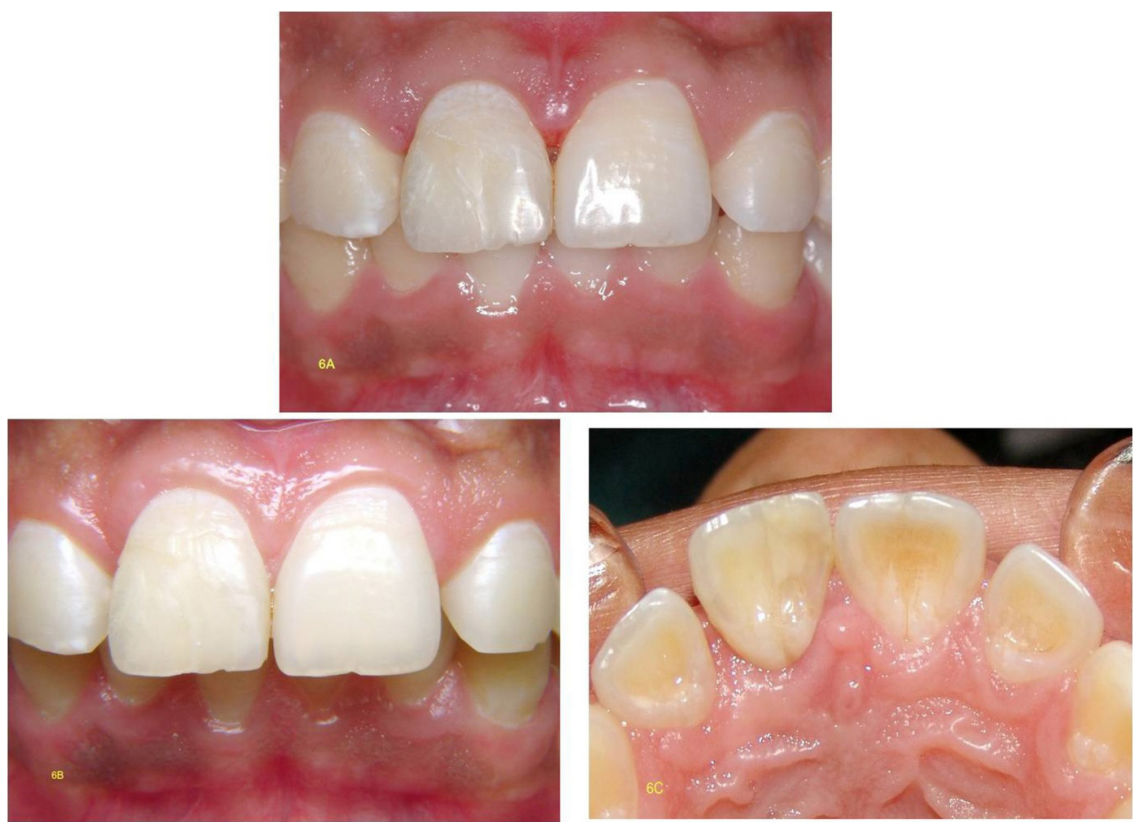

Figure 6. A) Case closed after removal of sutures (at 7 days); (B-C) Final outcome after 1 year; Observe the natural aesthetic obtained and the healthy appearance of the periodontium.

\section{DISCUSSION}

Periodontal involvement in crown-root fractures makes the prognosis of these cases difficult and requires a multidisciplinary approach. Planning should include a detailed diagnosis that evaluates the various aspects that orient the resolution of the case.
In the reported clinical case, the presence of fragments of satisfactory size and surface area favored the indication of an adhesive reattachment technique. The reattachment of fragments is a viable alternative for restoring anatomy, shape, contour, surface texture, occlusal alignment and the natural color of the fractured tooth, as the tooth structure is maintained in enamel, which has 
properties that are far superior to composite resins ${ }^{10}$. In the clinical case presented here, periodontal involvement was observed, restricted to the palatal surface, which oriented therapeutic procedure for carrying out periodontal surgery in order to re-establish the biological width only in that area, which is a region in which the aesthetic factor is not so critical. If the buccal surface had been involved, the most appropriate procedure would have been orthodontic extrusion ${ }^{1}$. According to Conceição et al. ${ }^{3}$, Olsburgh et al. ${ }^{8}$ and Campos et al. ${ }^{11}$, it is possible to confine gingivectomy and osteotomy to the areas where there has been invasion of the biological distances and to restrict the amount of bone removed to $1 \mathrm{~mm}$, that is to say, just enough to permit the absolute isolation of the operative field and the reinsertion of conjunctive tissue. When the fragment is reattached, the epithelial junction should have the capacity to be reinserted on the glued fragment, as the latter is composed of enamel and/or cement. To this end it is important that the bond line of the fragment with the remnant is as thin as possible. In the case in question, although there was a considerable loss of tooth structure at the buccal surface, the adaptation of the fragment to the remnant in the cervical areas was quite satisfactory. Moreover, the time that elapsed from the point of fracture should also be considered as a factor that contributes to the selection of the trans-operative fragment reattachment technique, since an orthodontic extrusion would have the effect of deferring the conclusion of the case, compromising aesthetics and putting at risk the endodontic treatment previously carried out ${ }^{12}$.

Due to the presence of areas with loss of tooth structure, giving rise to a lack of fragment adaptation, it was necessary to use flow composite resins to cement the fragments, and micro-hybrid resins to restore the areas where no fragments were available. The loss of structure may have also been the result of the fracture itself or, in the case of the palatal surface, by the earlier endodontic treatment, during the procedures undertaken to access and open the pulp chamber.

Several authors, including Maia et al. ${ }^{1}$, Palma-Dibb et al. ${ }^{13}$ and Ozel et al. ${ }^{14}$ have stated that the use of the adhesive system by itself, without any composite resin or resin cement, is sufficient to obtain an effective bond. On the other hand, other authors suggest that the combination of adhesive and composite resin could increase resistance of the adhesive interface with the fracture ${ }^{4-15}$. In all cases, however, the authors agree that it is not possible to do without the use of a composite resin when there is loss of tooth structure and the absence of a perfect fit between the fragment and tooth remnant. Accordingly, in the case in question, the use of low viscosity resin was chosen for the reattachment per se, so as to obtain a cementation line of minimal thickness due to the ease of flow of this type of resin ${ }^{11-16}$. In those areas that require a greater volume of composite resin, such as with the filling of the pulp chamber and in the mesiobuccal portion, use is made of micro-hybrid composite resins.

It was not necessary to use an intraradicular post for additional retention since, according to Loguercio et al. ${ }^{17}$, this does not increase resistance to the fracture in cases where the tooth fragment is reattached.

It is important to mention that, even with significant improvement in the clinical performance of the technique of reattaching dental fragments with the use of adhesive systems that employ total acid etching, it cannot be expected that the strength of the intact tooth will be restored after reattachment. Experimental studies have shown that resistance to shear fractures of glued teeth is inferior to that of intact teeth, although it has demonstrated results that are superior to composite resin restorations $s^{4-5,15}$. In the clinical case reported, the patient was duly informed of the possibility of a recurrence of fracture if there were no limitation on incisor function since, despite not having exhibited any parafunctional habits, the presence of an exaggerated overbite is a factor which is unfavorable to the reattachment prognosis, especially in cases of horizontal fracture ${ }^{12}$. In addition, the patient must always be informed of the possibility that the bond line between the fragment and the tooth remnant can still be seen, particularly when the smile line is high. These are limitations inherent to the reattachment technique, but are not contraindicated for use since, for the most part, patients prefer this form of treatment due to the prospect of being able to keep their own teeth.

The outcome of the case in question was relatively satisfactory as, although the bond line between tooth and fragment is not exactly imperceptible, contour, translucence and natural surface texture of the enamel were reestablished. Moreover, the emergence profile observed in the x-rays would be difficult to achieve using a restoration technique with composite resin or even a full crown.

\section{CONCLUSION}

The correct diagnosis of crown-root fractures is fundamental for the choice of the best restoration technique. The clinical case presented here was favorable 
to the indication of trans-operative reattachment of the fragments as periodontal involvement was restricted to an aesthetically non-critical area and the quality of the fragments provided a good surface area for adhesion. Although there may be limitations, such as the ineffectiveness of reestablishing the original resistance of the fractured tooth and the unpredictability of the aesthetic outcome in terms of color, the technique of reattaching the dental fragment, where possible, provides the best option for the restoration of previously fractured teeth, as it is the most conservative treatment and is safe, fast and, above

\section{REFERENCES}

1. Maia EA, Baratieri LN, Andrada MAC, Monteiro S, Araújo EM Jr. Tooth fragment reattachment: fundamentals of the technique and two case reports. Quintessence Int. 2003;34(2):99-107.

2. Stellini E, Stomaci D, Stomaci M, Petroni N, Favero L. Fracture Strength of tooth fragment reattachments with postpone bevel and overcontour reconstruction. Dent Traumatol. 2008;24(3):283-288. doi: 10.1111/j.1600-9657.2007.00539.x

3. Conceição EN. Colagem de fragmento dental. In: Conceição EN. Dentística: saúde e estética. Porto Alegre: ArtMed; 2000. p. 209-26.

4. Farik B, Munksgaard EC, Andreasen JO, Kreiborg S. Fractured teeth bonded with dentin adhesives with and without unfilled resin. Dent Traumatol. 2002;18(2):66-9. doi: 10.1034/j.16009657.2002.180203.x

5. Segun A, Ozer F, Unlu N, Ozturk, B. Shear bond strengths of tooth fragments reattached or restored. J Oral Rehabil. 2003;30(1):82-86. doi: 10.1046/j.1365-2842.2003.00978.x

6. Canoglu H, Gungor C, Cehreli ZC. Management of cervical root fracture using orthodontic extrusion and crown reattachment: a case report. Oral Surg Oral Med Oral Pathol Oral Radiol Endod. 2007;104(3):e46-49. doi:10.1016/j.tripleo.2007.03.030

7. Oliveira LD, Gomes APM, Gonçalves SEP, Valera MC. Tratamento endodôntico e estético de um incisivo central superior com fratura corono-radicular complexa. J Bras Clin Odontol Int. 2003;7(37):20-23.

8. Olsburgh $\mathrm{S}$, Jacoby T, Krejci I. Crown fractures in the permanent dentition: pulpal and restorative considerations. Dent Traumatol. 2002;18(3):103-115. doi: 10.1034/j.1600-9657.2002.00004.x

9. Campos RE, Quagliatto PS, Soares CJ. Fratura dental coronorradicular com envolvimento pulpar e do espaço biológico: abordagem multidisciplinar. Rev Ibero-Am Odontol Estet Dent. 2004;3(11):253-61. all, effective in restoring the attractiveness, function and harmony of the smile.

\section{Collaborators}

JCV Ribeiro took part in the design of the study, assisting with the clinical procedures and the composition of the manuscript. MM SILVA participated in the review of the bibliography and composition of the manuscript. CAO Fernandes performed the clinical procedures and took part in the revision and composition of the manuscript.

10. Silva AF, Piva E, Carvalho RV, Demarco FF. Alternativas clínicas para o tratamento de fraturas coronárias sem exposição pulpar. Rev Ibero-Am Odontol Estet Dent. 2004;3(11):231-40.

11. Campos EA, Mendonça AAM, Lima DM, Alvim HH, Andrade MF. Colagem de ragmento dentário: relato de casos clínicos. J Bras Clin Odontol Int. 2003;7(37):29-33.

12. Villat C, Machtou P, Naulin-Ifi C. Multidisciplinary approach to the immediate esthetic repair and long-term treatment of an oblique crown-root fracture. Dent Traumatol. 2004;20(1):56-60. doi: 10.1111/j.1600-4469.2004.00206.x

13. Palma-Dibb RG, Taba M, Santos CM, Navarro VP. Autogenous tooth fragment reattachment - association of periodontal surgery and endodontic and restorative procedures: a case report. Quintessence Int. 2004;35(3):179-84.

14. Ozel E, Cildir A, Ozel Y. Re-attachment of anterior tooth fragment using a self-etching adhesive: a case report. J Contemp Dent Pract. 2008;9(1):77-83.

15. Demarco FF, Fay R-M, Pinzon LM, Powers JM. Fracture resistance of re-attached coronal fragments - influence of different adhesive materials and bevel preparation. Dent Traumatol. 2004;20(3):157-63. doi: 10.1111/j.1600-4469.2004.00221.x

16. Yilmaz Y, Zehir C, Eyuboglu O, Belduz N. Evaluation of success in the reattachment of coronal fractures. Dent Traumatol. 2008;24(2):151-8. doi: 10.1111/j.1600-9657.2007.00532.x.

17. Loguercio AD, Leski G, Sossmeier D, Kraul A, Oda M, Patzlaff RT, et al. Performance of techniques used for re-attachment of endodontically treated crown fracture teeth. J Dent. 2008;36(4):249-55. doi: 10.1016/j.jdent.2008.01.001.

Received on: 17/6/2013

Final version resubmitted on: 24/9/2013

Approved on: 14/2/2014 